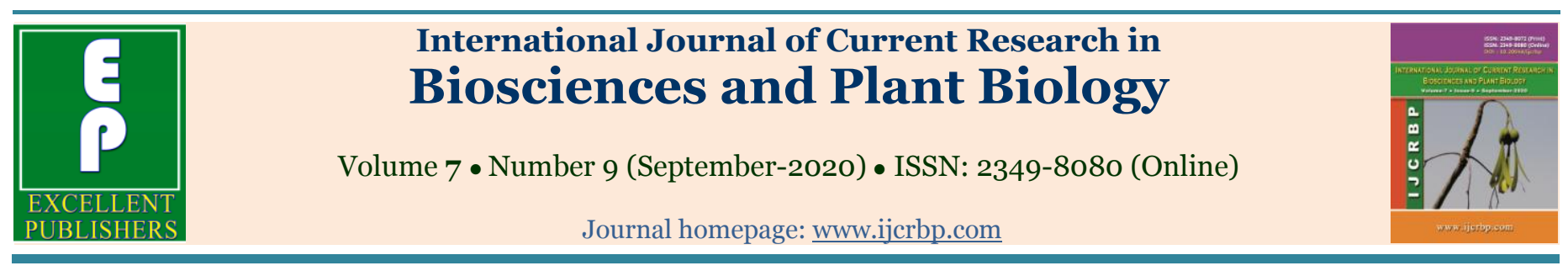

\title{
Carbon storage along altitudes in agrisilviculture system- Case study of Devprayag Block, Tehri District, Uttarakhand, India
}

\author{
K.K. Vikrant ${ }^{1 *}$, D.S. Chauhan² and R.H. Rizvi3 \\ ${ }^{1}$ Department of Forestry, Himalayanl College (Roorkee Institute of technology), Roorkee, Uttarakhand - 247 667, India \\ ${ }^{2}$ Department of Forestry \& NR, HNB Garhwal University, Srinagar, Garhwal, Uttarakhand - 246 174, India \\ 3Central Agroforestry Research Institute, Jhansi, Uttar Pradesh - 284 003, India \\ *Corresponding author; e-mail: kundankumarvikrant@gmail.com
}

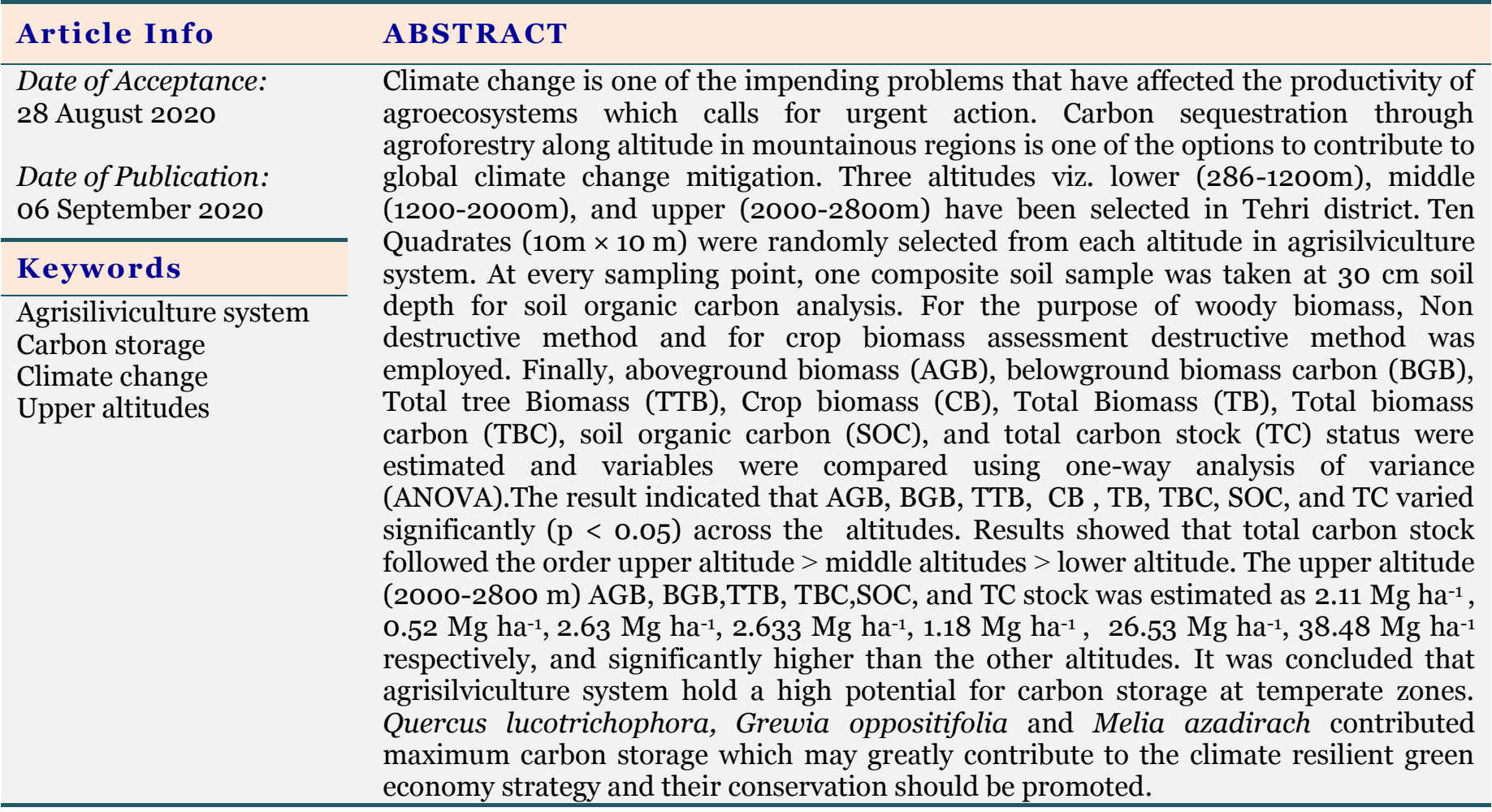

\section{Introduction}

Agroforestry is a sustainable land-use system which has a relationship with the farm working people to multipurpose tree species. Agroforestry systems are recommended to have good potential to carbon storage and thus highly important in mitigating the climate change. Global warming is mainly due to rising of $\mathrm{CO}_{2}$ levels in atmosphere. Carbon sequestration is very important for 
environment and economic benefits. According to the third assessment report of IPCC on climate change (IPCC 2000), agroforestry increases carbon storage capacity in farm lands. Agroforestry is a viable option to increase productivity of land and reduce the global warming (Dhayani et al., 2009). Integrated agroforestry land-use system is a kind of a short rotation plantation (SRP) in which fast growing tree species are managed in short coppicing cycles. Agroforestry utilize the available farm resources properly, maximize per unit production, optimize biological and physical resources and maintain ecological balance. An IPCC special report (IPCC, 2000) contains that conversion of wasteland and pasture land to agroforestry have potential for storage of atmospheric carbon. At the moment, National Action Plan for Climate Change (NAPCC, 2008) has exclusively emphasized the agroforestry interventions under its Green India mission. India has also emphasized on encouraging fast growing tree species for environment and economic benefit (National Agroforestry Policy, 2014). There are a number of short comings however, that need to be emphasized such as the change in vegetation under agroforestry systems, etc. (Albrecht and Kandji 2003).

In India, North-Western Himalayan region where people's dependence on forest resources is high, agroforestry systems can play an important role in environmental and ecological sustainability (Tiwari et al., 2018). Tree under different land use systems acts as storehouse of carbon by storing carbon in their tissues as biomass and thereby reducing the amount of atmospheric $\mathrm{CO}_{2}$ (Sarangle et al., 2018). Importance of agroforestry with respect to carbon sequestration and climate change mitigation effects is being widely recognized, but there is still paucity of quantitative data on agroforestry systems in Garhwal Himalaya. This study were conducted to determine the carbon stock capacity in agrisilviculture system in Devprayag block of Tehri Garhwal Himalaya and. Especially to measure the biomass carbon, soil organic carbon and total carbon storage in agrisilviculture system.

\section{Materials and methods}

The present investigations were conducted in Devprayag block in Tehri distt. of Garhwal
Himalaya, having an area of $217 \mathrm{~km}^{2}$, extended between $78^{\circ} 29^{\prime} \mathrm{E}$ to $79^{\circ} 10^{\prime} \mathrm{E}$ longitudes and $30^{\circ} 25^{\prime} \mathrm{N}$ to $30^{\circ} 30^{\prime} \mathrm{N}$ latitudes. It is a town in Tehri Garhwal in state Uttrakhand in India and is one of the Panch Prayag of Alaknanda and Bhagirathi rivers meet and take the Ganga river.

January is the coldest month whereas temperature becomes highest usually during June. Rainfall, in this study area, occurs almost throughout the year. Rainfall is maximum during the monsoon period i.e. from July to September. There is slight decrease in rainfall from December till March. Rest of the year rainfall is quiet low. Agriculture is the main occupation of the people. However, intensive cultivation is not possible as major part of the area is mountainous. Agricultural activities are common on gentle hill slopes and in relatively plain areas. Rice, wheat, mandua, barley, maize and sawan are the principal crops grown in this area. The area has been divided into three main agro-climatic zones viz: Sub tropical zone/ foot hill (300-1200m), Sub temperate zone/ middle altitude (1200-2000m) and temperate zone/ high altitude (2000- 2800m) altitudinal ranges depending on the topography, altitude and temperature condition (Singh and Singh, 1992). Geographical location of study area has been shown in Fig. 1.

\section{Sampling procedure}

Total six villages were selected for present study under Devprayag blocks, based on the altitudes three villages situated for in lower altitude (286 $1200 \mathrm{~m}$ ), two villages were situated in middle altitude $(1200-2000 \mathrm{~m})$ and one villages were situated in high altitude $(2000-2800 \mathrm{~m})$.Ten sample plots of $100 \mathrm{~m}^{2}$ size each were randomly laid out in agrisilviculture system in each altitude. The $\left(100 \mathrm{~m}^{2}\right)$ size plot was used for tree (woody perennials) enumeration and $1 \times 1 m$ size plot was used for (annuals i.e. agricultural crop, grass and weeds

\section{Structure of agrisilviculture system}

It is quite common throughout the block. This system is managed for the production of fuel, fodder, fibre and small timber trees with the agricultural corps. Agriculture crops such as wheat (Triticum aestivum), peas (Pisum sativum),potato (Solanum tuberosum),cauliflower (Brassica 
oleracea) and mustard (Brassica compestris) etc. during the winter season; and maize (Zea mays), tomato (Lycopersicon esculentum), pepper (Pepper nigrum) and french bean (Phaseolus vulgaris) etc. during the summer season are grown in monoculture or mixed cropping on the permanent terraces prepared across the hill slopes, while fodder, fuel and timber trees such as Grewia oppostifolia, Celtis australis, Bauhinia variegata, B. purpuera, Albizia leeback etc are deliberately left or grown on the bunds of terraces.

\section{Carbon stock assessment}

Density in each study sites was studied using quadrat method (Misra, 1968). Aboveground biomass of tree was measured components wise which includes stem biomass, branch biomass and leaf biomass which were estimated by nondestructive method. All trees falling in the plot $\left(100 \mathrm{~m}^{2}\right)$ were enumerated. The DBH (diameter at breast height i.e. $1.37 \mathrm{~m}$ ) was measured with tree caliper and height with Haga altimeter.

Bole volume was measured with bark using the formula $\boldsymbol{V}=\boldsymbol{f} \boldsymbol{X} \boldsymbol{h} \boldsymbol{X} \boldsymbol{g}$ and $\boldsymbol{f}=\mathbf{2} \boldsymbol{h}_{\mathbf{1}} / \mathbf{3} \boldsymbol{h}$ was given by (Presseler, 1865). Stem biomass was estimated by multiplying the stem volume with wood specific gravity (IPCC, 2006). Wood specific gravity of different agroforestry species were used as reported value of Rajput et al. (1985), Raturi et al. (2002), Purkashyatha (1982), and Chaturvedi et al. (2012) was given in Table 1.

For the assessment of branch wood biomass, total number of branches irrespective of size were counted on each of the sample tree, then these branches were categorized on the basis of basal diameter into three groups viz., $<6 \mathrm{~cm}, 6-10 \mathrm{~cm}$ and $>10 \mathrm{~cm}$. From each of sampled tree two branches from each group were randomly selected and weighed fresh weight. Sub samples of each component were oven dried to constant weight at $65^{\circ} \mathrm{C}$. The following formula (Chidumaya, 1990) was used to determine the dry weight of branches:

$$
B_{d w i}=B_{f w i} / \mathbf{1}+M_{c b d i}
$$

Leaves from the sampled branches were also removed, weighed and oven dried separately to a constant weight at $80 \pm 50^{\circ} \mathrm{C}$ to determine leaf biomass (Chidumaya, 1990).The total above ground biomass was the sum of stem biomass, branch biomass and leaves biomass (Kanime et al., 2013). Below ground biomass of tree was calculated by multiplying the aboveground biomass by a factor of 0.25 for broad-leaved species and 0.20 for coniferous species (IPCC 1996).The biomass of tree was estimated from the sum of above ground biomass and below ground biomass of tree. Crop biomass was estimated using one $\mathrm{m}^{2}$ quadrates by a destructive method. During 2015-2016, when the crops were at their peak biomass in March to April for Rabi (winter) and August to September for Kharif (summer) seasons. All the agricultural crops, grasses and weeds plants occurring within the border of the quadrats were harvested at ground level and sorted out and collected samples were weighted. Fresh weight was converted into dry weight on the basis of plant samples kept in the oven dried at $80^{\circ} \mathrm{C}$ for 24 hours. The crop biomass was converted into carbon by multiplying with a factor of 0.45 (Woomer, 1999).Total biomass carbon stock of agroforestry system was the sum of total biomass carbon of trees and total biomass carbon of crops. The biomass carbon was estimated from total biomass was converted into carbon (C) by a factor of 0.45 (Woomer, 1999). In agroforestry area, 10 sample plots of $10 \mathrm{~m} \times 10 \mathrm{Om}$ were randomly laid out. One Soil sample were taken at the depth of o-10, 10-20 and 20-30 cm from each sample plot and Bulk density was determined by the weighing bottle method (Singh, 1980), and organic C was determined using the Walkley and Black (1934) method. Soil organic carbon was calculated by using the equation given by Pearson et al. (2007). Soil Organic Carbon stock (t / ha) = Soil bulk density $(\mathrm{g} \mathrm{cm} 3) \times$ Soil depth (cm) x Carbon (\%)]. Plant sample and soil samples were processed in the laboratory. Soil analysis was carried out in soil laboratory at Central Agroforestry Research Institute (CAFRI), Jhansi, U.P, India.

\section{Statistical analysis}

The data was analyzed applying one-way analysis of variance (ANOVA) wherever the effects exhibited significance at $\mathrm{P} \leq 0.05$ probabilities, the least significant difference (LSD) was calculated. Pearson correlation coefficient $\left(\mathrm{r}^{2}\right)$ was done for the analysis of correlation among the studied parameters. All Analysis was performed using computer based software. 

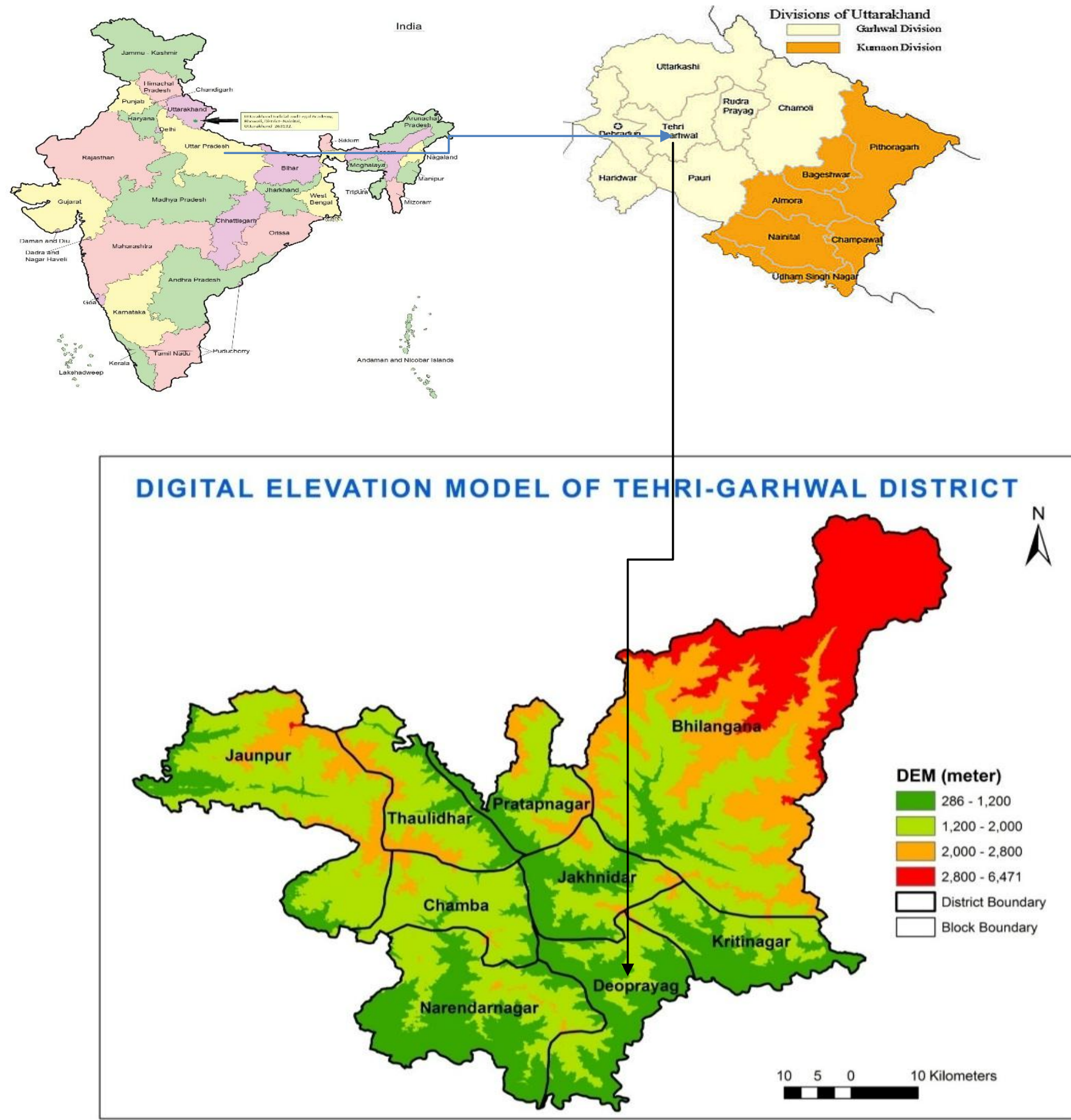

Fig. 1: Geographical location of study area. 


\section{Results}

Farmer's practices agrisilvicultural system (trees and agriculture crops are growing in same price of land). It is quite common throughout the block. This system is managed for the production of fuel, fodder, fibre and small timber trees with the agricultural corps. During collection of primary data, Exiting agroforestry species in agrisilviculture system has been shown in Table 2 . The common existing agroforestry tree species at middle altitude, tree species like Quercus leucotrichophora, Grewia oppositifolia, Melia azedarach, Rhododendron arboretum, Celtis australis and Toona ciliata. In lower altitude, tree species are Adina cordifolia, Grewia oppositifolia, Melia azedarach, Celtis australis and Bahumeria racemosa were common. The only one tree species Quercus leucotrichophora was found at upper altitude (Table 2). The common existing agricultural crop species at middle altitude, crop species like Echinochola Frumentoacea, Glycine max, Cajanus cajan, Amarnathus blitum, Phaseolus vulgaris, Vigna mungo In lower altitude, crop species are Echinochola frumentoacea, Vigna mungo, Cajanus cajan, Amarnathus blitum, Sesamum indicum and Glycine $\max$ were common. In upper altitude, Echinochola Frumentoacea, Phaseolus vulgaris, Vigna mungo were found. Grewia oppositifolia, Celtis australis, Melia azadirach and Quercus leucotrichophora are major species and mostly adopted by farmer in study area.

Considering the effect of altitudes on tree density, the variation reveals that tree density was differs significantly $(\mathrm{P} \leq 0.05)$. At the middle altitude maximum tree density was recorded (265 tree ha-1) followed by ( 175 tree ha $^{-1}$ ) at upper altitude (Table $3)$. It can be owed to the fact that elevation gradients create varied climates along with resultant soil differentiation that promote the diversification of plant species (Brown 2001). Vikrant et al. 2018 also reported that middle altitude (1200-2000m) contributed maximum agroforestry area in Tehri district of Garhwal Himalaya. Effect of altitudes on volume was differing significantly ( $\mathrm{P} \leq$ 0.05). Maximum volume was recorded (2.5.4 $\left.\mathrm{m}^{3} \mathrm{ha}^{-1}\right)$ at the upper altitude followed by $\left(0.41 \mathrm{~m}^{3} \mathrm{ha}^{-1}\right)$ at middle altitude (Table 3). Quercus leucotrichophora were found only at high density at Upper altitude. Due to better tree attributes (bole, crown spread, crown length, leaf area) of Quercus species, upper altitudes contained maximum tree volume. Above ground biomass was significantly $(\mathrm{P} \leq \mathrm{0.01})$ different with the altitudes it has been found maximum (2.11 $\mathrm{Mg} \mathrm{ha}^{-1}$ ) at upper altitude followed by (0.34 $\left.\mathrm{Mg} \mathrm{ha}{ }^{-1}\right)$ at middle altitude. The differences in the productivity of agrisilviculture systems may also be due to differences in soil conditions, phenology of dominant species (Gupta and Singh 1981). Table 3 highlighted that the below ground biomass was significantly $(\mathrm{P} \leq 0.01)$ different along altitudes. it was found maximum (0.52 $\mathrm{Mg} \mathrm{ha} \mathrm{h}^{-1}$ ) at upper altitudes followed by (0.08 $\mathrm{Mg} \mathrm{ha}^{-1}$ ) at middle altitude. The belowground biomass observed as fine roots was significantly higher in Quercus species with their respective values. The results clearly shows that the quantifying the influence of agrisilviculture system structure, land type and management on biomass production levels. The results show that total tree biomass significantly $(\mathrm{P} \leq \mathrm{0.01})$ different with altitudes was recorded maximum $(2.63 \mathrm{Mg}$ $\left.\mathrm{ha}^{-1}\right)$ at upper altitude followed by (0.42 $\left.\mathrm{Mg} \mathrm{ha}^{-1}\right)$ at the middle altitude (Table 3).). If we see the maximum tree density and volume has been found at upper altitudes of tree species are Quercus leucotrichophora were planted at high density.

Effect of variation of crop biomass was significantly $(\mathrm{P} \leq \mathrm{0.01})$ different on altitudes, was recorded maximum (0.006 $\mathrm{Mg} \mathrm{ha}^{-1}$ ) at middle altitude followed by (0.003 $\left.\mathrm{Mg} \mathrm{ha}^{-1}\right)$ at lower and middle altitude (Table 3 ). The variation in annual crop biomass can be explained due to the tree-crop interaction effects. The reduced biomass may be due to more competition for resources like nutrients, moisture and light compared to the tree species (Kumar et al., 2012).

The following analysis revealed that total biomass differ significantly $(\mathrm{P} \leq 0.05)$ with altitudes. Table 3 represents that the total biomass was higher (2.633 $\mathrm{Mg} \mathrm{ha}^{-1}$ ) at the upper altitude followed by $\left(0.426 \mathrm{Mg} \mathrm{ha}^{-1}\right)$ at middle altitude. Tree density and volume of Quercus leucotrichophora was also showed higher at this altitude may be the region for higher biomass. The data showed that the biomass carbon stock was significantly $(\mathrm{P} \leq 0.05)$ different across the altitudes which was recorded maximum (1.18 $\mathrm{Mg} \mathrm{C} \mathrm{ha}^{-1}$ ) at upper altitude while 
minimum (o.19 $\mathrm{Mg} \mathrm{C} \mathrm{ha-1}^{-1}$ at lower altitude (Table 3). Biomass carbon has been found maximum at upper altitude because the presences of the tree species namely, Quercus species. It is confirmed that Quercus leucotrichopora had provides better tree attributes (bole, crown spread, crown length, leaf area) and well developed root system may be contributing more biomass than other agrofoerstry species. Biomass in Quercus leucotrichophora was higher as reported by (Devi et al., 2013; Sharma et al., 2010) for lower Western Himalaya.

\section{Density contribution by tree species in agrisilviculture system}

In the district across altitudes and systems, total eight agroforestry trees species were observed. Out of eight, Grewia oppositifolia, Celtis australis, Melia azedirach, Quercus leucotrichophora, are most promising and dominant agroforestry tree species in block. . Table 4 showed that among the dominant tree speciesby Quercus leucotrichophora was contributes maximum density (43.65\%) followed by Grewia oppositifolia (29.78\%) and rest of species have contributes (26.57\%) density in the block.

In the present study, Quercus lucotrichophora contributed maximum density as compared to other species across agroforestry area of Devprayag block. It indicated that Quercus lucotrichophora based agroforestry occupied most of agroforestry area in Devprayag block.

\section{Volume contribution by trees in agrisilviculture systems}

Total eight agroforestry trees species were contributed volume in the block. Out of eight, Grewia oppositifolia, Melia azedirach, Quercus leucotrichophora, were containing maximum volume in the block. Table 4 represents that among the dominant tree species Quercus leucotrichophora was contributes maximum (87.58\%) volume followed by Grewia oppositifolia ( $7.65 \%)$ and rest of species were contributes (4.77\%) in the block In the present study, Quercus leucotrichophora contributed maximum volume then other tree species.

It is confirmed that Quercus leucotrichopora had provides better tree attributes (bole, crown spread, crown length, leaf area) and well developed root system may be contributing more volume than other agrofoerstry species.

\section{Biomass carbon stock contribution by trees in agrisilviculture systems}

Talking to biomass carbon stock, total eight agroforestry trees species were contributed biomass carbon in the district. Out of eight, Grewia oppositifolia, Melia azedirach, Quercus leucotrichophora, were containing maximum biomass carbon stock in the block. Table 4 represents that among the dominant tree species Quercus leucotrichophora was contributes maximum (89.72\%) biomass carbon stock followed by Grewia oppositifolia (5.32\%) and rest of species were contributes $(4.96 \%)$ in the block In the present study, Quercus leucotrichophora contributed maximum biomass then other tree species. It is confirmed that Quercus leucotrichopora had provides better tree attributes (bole, crown spread, crown length, leaf area) and well developed root system may be contributing more biomass than other agrofoerstry species. Biomass in Quercus leucotrichophora was higher as reported by (Devi et al., 2013; Sharma et al., 2010) for lower Western Himalaya.

\section{Biomass carbon stock contribution by crop in agroforestry systems}

As far as biomass carbon stock is concerned, total seven agroforestry crops species were observed in the district. Out of seven, maximum biomass carbon containing crop species are Vigna mungo (20\%), Glycin max (20\%), Echinochloa frumentacea (20\%), and rest of the species contributes (40\%) biomass carbon stock (Table 4).

Considering the altitudes bulk density did not show significantly different with altitudes, it was positively correlated with altitudes but the variation indicates there was no effect on altitudes the values was more or less similar in all the altitudes (Table 5). The reduction of bulk density of soil due to increase in soil organic carbon has been amply reported literatures (Coot and Ramsay, 1983; Sharma et al., 1995). The SOC\% was significantly ( $\mathrm{P} \leq 0.01)$ different and positively correlated with altitudes, it was observed that it increased with the increasing altitudes. The value 
of SOC\% was found minimum (2.43\%) at the lower altitude and maximum (3.00 \%) at upper altitude (Table 5). It is evidently shows that the soil organic carbon was significantly influenced due to land use system and increased organic carbon content in soils under tree based system may be due to more leaf litter deposition and root turnover from trees (Zegeye, 1991). The present study shows that organic carbon increased with increasing altitudes which can be owed to continuous accumulation of leaf litter and lower decomposition rate at the higher altitude than at lower altitude. Slower decomposition means less mineralization and hence losses of organic carbon through erosion will be lower at higher altitude and hence more carbon content (Bhardwaj et al., 2013). Effect of soil organic carbon on altitudes was given in table 5 showed that SOC was found significantly $(\mathrm{P} \leq \mathrm{0.01})$ different and positively correlated with altitudes it was increased with the increasing altitudes. The value of SOC was recorded higher (26.53 $\left.\mathrm{Mg} \mathrm{ha}^{-1}\right)$ at upper altitude then other. In our study, we found that the organic carbon increased with increasing altitudes which can be owed to continuous accumulation of leaf litter and slower decomposition rate at the higher altitude than at lower ones. Slower decomposition means less mineralization and hence losses of organic carbon through erosion will be lower at higher altitude and hence more carbon content (Bhardwaj et al. 2013). Chisanga (2020) reported that tree-based agroforestry system can be ascribed to continuous locking up of carbon in trees and regular addition of leaf litter to the soil, which helps in the buildup of higher amount of carbon of high-altitude dry temperate land use systems in North Western Himalaya. Singh et al. (2018) recommended for sequestration of the atmospheric $\mathrm{CO}_{2}$ in the soil pool at higher elevation.

Total carbon stock is shown in Fig. 2. Total carbon stock were recorded maximum in order of upper altitude (2000-2800 m) > middle altitude (1200$2000 \mathrm{~m}$ ) > lower altitude (286-1200 m). Upper altitude contain maximum total carbon stock (38.48 $\mathrm{Mg} \mathrm{ha}^{-1}$ ) follow by middle altitude (27.95 $\mathrm{Mg} \mathrm{ha}^{-1}$ ) and minimum was recorded by lower altitude (14.17 $\left.\mathrm{Mg} \mathrm{ha}^{-1}\right)$. At upper altitude, only one tree species Quercus leucotrichophora were found with high density and volume. Due to continuous accumulation of leaf and better tree structure of Quercus species, Total carbon tock were found maximum at upper altitudes. Vikrant et al. (2020) also reported that temperate zone/upper altitude contributes maximum carbon stock in agrisilviculture system.

Table 1. Specific gravity of agroforestry species.

\begin{tabular}{llll}
\hline Sl. No. & Species & Specific gravity & Source \\
\hline 1 & Quercus leucotrichophora & 0.826 & Raturi et al. (2002) \\
2 & Grewia oppositifolia & 0.606 & Purkayastha (1982) \\
3 & Melia azedirach & 0.491 & Raturi et al. (2002) \\
4 & Celtis australis & 0.444 & Rajput et al. (1985) \\
5 & Toona ciliata & 0.424 & Raturi et al. (2002) \\
6 & Adina cardifolia & 0.583 & Raturi et al. (2002) \\
7 & Bahumeria racemosa & 0.52 & Chaturvedi et al. (2012) \\
8 & Rhododendron arboreum & 0.512 & Rajput et al.(1985) \\
\hline
\end{tabular}

Table 2. Exiting agroforestry species in agrisilviculture system

\begin{tabular}{|c|c|c|c|c|}
\hline $\begin{array}{l}\text { Altitudes } \\
\text { (m) }\end{array}$ & Village & Tree species & Crops & GPS location \\
\hline $1200-2000$ & Dungi, Langur & $\begin{array}{l}\text { Quercus leucotrichophora, } \\
\text { Grewia oppositifolia, Melia } \\
\text { azedarach, Rhododendron, } \\
\text { Celtis australis, Toona cilita }\end{array}$ & $\begin{array}{l}\text { Echinochola frumentoacea, Glycine } \\
\text { max, Cajanus cajan, Amarnathus } \\
\text { blitum, Phaseolus vulgaris, Vigna } \\
\text { mungo }\end{array}$ & $\begin{array}{l}78^{\circ} .601 \text { to } 78^{\circ} 605 \\
\mathrm{~N} \& 30^{\circ} .22 \text { to } \\
30^{\circ} .23 \mathrm{~S}\end{array}$ \\
\hline $2000-2800$ & Jurana & Quercus leucotrichophora & $\begin{array}{l}\text { Echinochola frumentoacea, } \\
\text { Phaseolus vulgaris, Vigna mungo }\end{array}$ & $\begin{array}{l}78^{\circ} .58 \text { to } 78^{\circ} 61 \mathrm{~N} \& \\
30^{\circ} .002 \text { to } \\
30^{\circ} .008 \mathrm{~S}\end{array}$ \\
\hline
\end{tabular}


Table 3. Density (no. of trees ha-1), volume $\left(\mathrm{m}^{3} \mathrm{ha}^{-1}\right)$, biomass and biomass carbon stock $\left(\mathrm{Mg}^{-1} \mathrm{a}^{-1}\right)$ in agrisilviculture system along altitudes

\begin{tabular}{llllllllllll}
\hline $\begin{array}{l}\text { Altitudes } \\
\text { (M) }\end{array}$ & Density & Volume & $\begin{array}{l}\text { Stem } \\
\text { biomass }\end{array}$ & $\begin{array}{l}\text { Branch } \\
\text { biomass }\end{array}$ & $\begin{array}{l}\text { Leaf } \\
\text { biomass }\end{array}$ & AGB & BGB & TTB & CB & TB & TBC \\
\hline $286-1200$ & 150 & 0.33 & 0.1 & 0.06 & 0.02 & 0.18 & 0.04 & 0.22 & 0.003 & 0.223 & 0.1 \\
$1200-2000$ & 265 & 0.41 & 0.24 & 0.07 & 0.03 & 0.34 & 0.08 & 0.42 & 0.006 & 0.426 & 0.19 \\
2000-2800 & 175 & 2.54 & 1.2 & 0.65 & 0.26 & 2.11 & 0.52 & 2.63 & 0.003 & 2.633 & 1.18 \\
LSD 0.05 & 44 & 1.7 & 0.34 & 0.25 & 0.15 & 1.43 & 0.35 & 1.78 & 0.002 & 1.782 & 0.8 \\
\hline
\end{tabular}

Significance at the level of probability of $5 \%(\mathrm{P} \leq 0.05) ;{ }^{*} \mathrm{AGB}=$ Above ground biomass $\mathrm{BGB}=\mathrm{Below}$ ground biomass $\mathrm{TTB}=$ Total tree biomass $\mathrm{CB}=$ crop biomass $\mathrm{TB}=$ Total biomass $\mathrm{TBC}=$ Total biomass carbon.

Table 4. Density (no. of trees $\left./ 1 \mathrm{oom}^{2}\right)$, volume $\left(\mathrm{m}^{3} / 100 \mathrm{~m}^{2}\right)$, biomass and biomass carbon stock $\left(\mathrm{Kg} / 100 \mathrm{~m}^{2}\right)$ in agrisilviculture system across altitudes (286-2800m). Percentage indicates contribution.

\begin{tabular}{|c|c|c|c|c|c|c|}
\hline Species & Density & Volume & AGB & BGB & TB & TBC \\
\hline \multicolumn{7}{|l|}{ Tree species } \\
\hline G. oppositifolia & $6.40(29.78 \%)$ & $26.11(7.65 \%)$ & 16.70 & 4.18 & 20.88 & $9.39(5.32 \%)$ \\
\hline Q. lucotrichophora & $9.38(43.65 \%)$ & $298.95(87.58 \%)$ & 281.73 & 70.43 & 352.16 & $158.47(89.72 \%)$ \\
\hline C. australis & $1.36(6.33 \%)$ & $0.05(0.02 \%)$ & 1.81 & 0.45 & 2.26 & $1.02(0.58 \%)$ \\
\hline M. azadirach & $1.16(5.40 \%)$ & $12.79(3.75 \%)$ & 8.57 & 2.14 & 10.71 & $4.82(2.73 \%)$ \\
\hline B. racemosa & $0.73(3.40 \%)$ & $2.81(0.82 \%)$ & 1.21 & 0.30 & 1.51 & $0.68(0.39 \%)$ \\
\hline T. ciliata & $0.60(2.79 \%)$ & $0.57(0.17 \%)$ & 1.13 & 0.28 & 1.41 & $0.64(0.36 \%)$ \\
\hline A. cordifolia & $0.93(4.33 \%)$ & $0.05(0.01 \%)$ & 1.53 & 0.38 & 1.91 & $0.86(0.49 \%)$ \\
\hline R. arboretum & $0.93(4.33 \%)$ & $0.02(0.01 \%)$ & 1.33 & 0.33 & 1.66 & $0.75(0.42 \%)$ \\
\hline \multicolumn{7}{|l|}{ Crop species } \\
\hline Vigna mungo & & & & & 0.06 & $0.03(20 \%)$ \\
\hline Glycine max & & & & & 0.08 & $0.03(20 \%)$ \\
\hline Amarnathus blitum & & & & & 0.04 & $0.02(13 \%)$ \\
\hline Phaseolus vulgaris & & & & & 0.04 & $0.02(13 \%)$ \\
\hline Sesamum indicum & & & & & 0.03 & $0.01(6 \%)$ \\
\hline Cajanus sp. & & & & & 0.03 & $0.01(6 \%)$ \\
\hline Echinochloa frumentacea & & & & & 0.07 & $0.03(20 \%)$ \\
\hline
\end{tabular}

${ }^{*} \mathrm{AGB}=$ Above ground biomass $\mathrm{BGB}=$ Below ground biomass $\mathrm{TB}=$ Total biomass $\mathrm{TBC}=$ Total carbon.

Table 5. SOC\%, bulk density and soil organic carbon along altitudes.

\begin{tabular}{llll}
\hline Altitudes & Bulk density & SOC (\%) & SOC (Mg ha-1) \\
\hline $286-1200$ & 0.20 & 2.43 & 13.02 \\
$1200-2000$ & 0.28 & 2.88 & 25.90 \\
$2000-2800$ & 0.30 & 3.00 & 26.53 \\
$\mathrm{LSD}_{0.05}$ & 0.039 & 0.11 & 5.28 \\
\hline
\end{tabular}

Significance at the level of probability of $5 \%(\mathrm{P} \leq 0.05) ;{ }^{*} \mathrm{SOC}=$ Soil organic carbon.

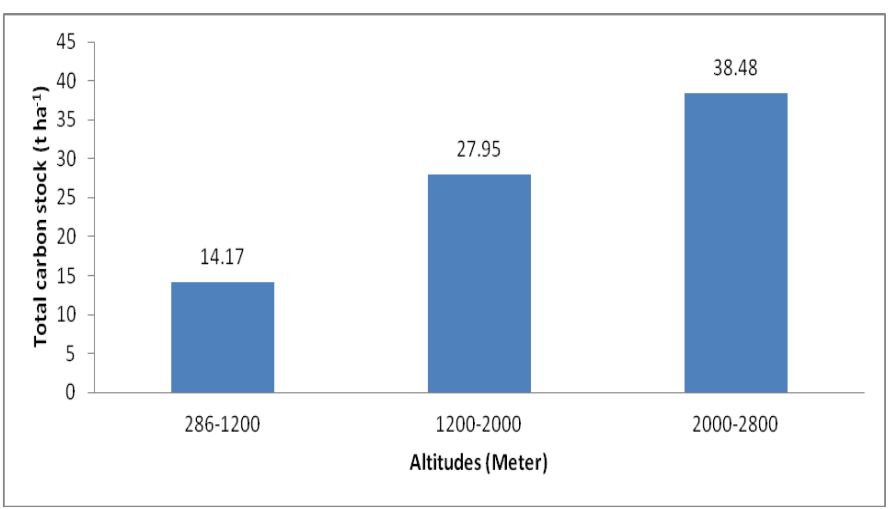

Fig. 2: Total carbon stock along altitudes in agrisilviculture system

\section{Conclusion}

The study displays that agrisilviculture system had significant variation along altitudes in their total carbon storage level. It was concluded that upper altitude/temperate zone (2000-2800 m) contain maximum carbon store in Devprayag block and positively correlated wth altitudes. Quercus lucotrichophora, Grewia oppositifolia and Melia azadirach are dominant species and mostly adopted by the farmers which contributed towards tapping atmospheric $\mathrm{CO}_{2}$ vis-à-vis mitigation of climate change. Therefore, these three species were considered suitable agroforestry tree species in the 
block. Thus agrisilviculture systems are playing an important role in the biodiversity conservation, soil enrichment, and carbon storage and improving the economic status of the farmers in Devprayag block of Tehri district of Uttarakhand. Hence these systems need to be promoted further for economic and environmental security.

\section{Acknowledgement}

First author thanks to Director ICAR-Central Agroforestry Research Institute, Jhansi who provided soil laboratory facilities for estimation of soil organic carbon. Authors are also thankful to Prof. N.P.Todaria, Head (Retired), Department of Forestry and NR, HNB Garhwal University, Srinagar Garhwal, Uttarakhand for guidance during the course of present work and UGC, New Delhi for providing Rajiv Gandhi National Fellowship (Grant No. RGNF-2012-13-SC-BIH30641). The authors are very thankful to the farmers of Tehri Garhwal who facilitate during field work

\section{References}

Albrecht, A, Kandji, S.T., 2003. Carbon sequestration in tropical agroforestry systems, Agric. Ecosyt. Environ. 99:15-27.

Bhardwaj, D.R., Sanneh, A., Bhalendra, S.R., Kumar, Sanjeev., 2013. Status of Soil Organic Carbon Stocks Under Different Land Use Systems in Wet Temperate North Western Himalaya. J of Tr Sci. 32 (1\&2): 14-22.

Brown, J., 2001. Mammals on mountain sides: Elevation patterns of diversity. Glo Eco Biogeo.10: 101-109.

Chaturvedi, R.K.,, Raghubansi, A.S., Singh, J.S., 2012. Biomass estimation of dry tropical wood species at juveline stage. Scient Wood J. 1-5pp.

Chidumayo, E.N.1990. Above-ground woody biomass structure and productivity in a Zambezian woodland. For Ecol \& Mngt. 36: 33-46.

Chisanga, Kafula ., Bhardwaj, D. R., Nazir, A. Pala., C. L. Thakur., 2018. Biomass production and carbon stock inventory of high-altitude dry temperate land use systems in North Western Himalaya, Eco Proc. (2018) 7:22.

Coote, R.D., Ramsey, J.F., 1983.Quantification of the effect of over 35 years of intensive cultivation on four soils. Canadian J Soil Sci.
63: $1-74$.

Devi, B., Bhardwaj, D.R., Panwar, P., Pal, S., Gupta, N.K., Thakur, C.L., 2013. Carbon allocation, sequestration and $\mathrm{CO}_{2}$ mitigation under plantation forest of North-Western Himalaya, India. Ann For. Res. 56(1): 123-135.

Dhyani, S.K., Kareemulla, K.A., Handa, A.K., 2009. Agroforestry potential and scope fordevelopment across agro-climatic zones in India. Ind J for 32(2):181-190.

Dixon, R.K., Brown, S., HoughMg, R.A., Solomon, A.M., Trexler, M.C., 1994. Carbon pools and fluxes of global forest ecosystems. Sci. 263: 185-190.

Gupta, S.R., Singh, J.S., 1981. Influence of floristic composition on the net primary production and dry matter turnover in tropical grassland. Aust J of Econ.. 7: 363-374.

IPCC, 1996. Revised IPCC guidelines for national greenhouse gas inventories. Cambridge: Cambridge University Press

IPCC, 2000. Land use and land use change and forestry. A special report, Cambridge:Cambridge University Press

IPCC, 2006. IPCC guidelines for national greenhouse gas inventories, Cambridge:Cambridge University Press

Jha, M.N., Gupta, M.K., Raina, A.K., 2001. Carbon Sequestration: Forest soil and land use management. Annals of For. 9: 249-256.

Kumar, Sanjeev., Verma, K.S., Kumar, Naresh., 2012. Above ground carbon sequestration potential of agroforestry system of Western Himalaya. J of tr sci. 31 (1\& 2) 20-28.

Mishra, R., 1968. Ecology work book. Oxford/IBH Publishing, New Delhi. 243pp

NAFP, 2014. National Agroforestry Policy, Government of India, Department of agriculture \& cooperation, Ministry of agriculture, New Delhi, 1-13pp.

NAPCC, 2008. Nation action plan on climate change, Government of India, Prime minister's council on climate change. 1-56pp.

Pearson, T.R., Brown. S.L., Birdsey, R.A., 2007. Measurement guidelines for the sequestration offorest carbon, U.S.: Northern Research Station, United States Department ofAgriculture. pp.1-47.

Pressler, M. 1865. Das Gestz der Stammformbildung. Leipzig: Verlag Arnold. **

Purkayastha, S.K. 1982. Indian Woods: Their Identification, Properties and Uses, Delhi, 
India: The Controller of Publications. 4: 172

Rajput, S.S., Shukla, N.K., Gupta, V.K., .1985. Specific gravity of Indian timber. J Timber Dev Assoc India. 31(3): 12-41.

Raturi, R.D., Chauhan, L., Gupta, S., Vijendra, R.R., 2002. Indian Woods: Their Identification, Properties and Uses. Dehra Dun, India: ICFRE Publication.

Sarangle, S., Rajasekaran, A., Benbi, DK., Chauhan. S.K., 2018. Biomass and carbon stock, carbon sequestration potential under selected land use systems in Punjab. Fore Res \& Engin: Inter J. 2 ( 2): 1-6.

Sharma, C.M., Baduni, N.P., Gairola,S., Ghildiyal, S.K., Suyal, S., 2010. Tree diversity and carbon bstocks of some major forest type of Garhwal Himalaya, India. For Ecol \& Mngt. 260: 21702179.

Sharma, R., Sharma, E., Purohit, A.N. 1995. Dry matter production and nutrient cycling inagroforestry systems of mandarin grown in association with Albizia and mixed tree species. Agrofores Syst. 29:165-179.

Sing Matber., Gupta, bhupendra., Das, H.K., 2018. Soil organic carbon density under different agroforestry systems along an elevation gradient in north-western Himalaya. Range Mgmt. \& Agrofor. 39 (1) : 8-13, 2018.

Singh, J.S., Singh, S.P., 1992. Forests of Himalaya: Structure, Functioning and Impact of Man. Gyanodaya Prakashan, Nainital, Uttarakhand, India. 294 p.

Tiwari, P., Pant, K. S., Singh, R., 2018. Biomass apprisal of pasture based agroforestry systems in North-Western Himalaya, India. Inter $\mathrm{J}$ of Chemi stu. 6 (6): 1792-1798.

Vikrant, K.K., Chauhan, D.S., Rizvi, R.H. 2020. Carbon Stock Assessment along Altitudes in Agrisilviculture Systems of Tehri District, Uttarakhand, North Western Himalaya- Case study of Pratapnagar block, In For , 146(3), 202-207.

Walkley, A.J., Black, I. 1934. Estimation of soil organic carbon by chromic acid titration method. Soil Sci. 37: 29-38.

Woomer, P.L. 1999. Impact of cultivation of carbon fluxes in woody savannas of Southern Africa. Wate Air \& Soi. Poll 70: 403-412

Zegeye, M.W. 1999. Tree crop interaction studies in agri-horti-silviculture system. M.Sc Thesis, Dr. Y. S. Parmar University of Horticulture and Forestry, Nauni, Solan (HP).

\section{How to cite this article:}

Vikrant, K.K., Chauhan, D.S. and Rizvi, R.H. 2020. Carbon storage along altitudes in agrisilviculture system- Case study of Devprayag Block, Tehri District, Uttarakhand, India. Int. J. Curr. Res. Biosci. Plant Biol. 7(9), 29-38. doi: https://doi.org/10.20546/ijcrbp.2020.709.004 